\title{
Trace metals in Posidonia oceanica in a coastal area of the Ionian Sea (Calabria, Italy)
}

\author{
Radiana Cozza*, Adele laquinta, Davide Cozza, Luisa Ruffolo
}

Dipartimento di Biologia, Ecologia e Scienze della Terra, Università della Calabria, Arcavacata di Rende, Cosenza, Italy;

*Corresponding Author: radiana.cozza@unical.it

Received 25 January 2013; revised 26 February 2013; accepted 22 March 2013

Copyright (C) 2013 Radiana Cozza et al. This is an open access article distributed under the Creative Commons Attribution License, which permits unrestricted use, distribution, and reproduction in any medium, provided the original work is properly cited.

\section{ABSTRACT}

As, $\mathrm{Cd}, \mathrm{Cu}$ and $\mathrm{Pb}$ concentrations were measured in Posidonia oceanica sampled from meadows located in two sites along the calabrian coast (Ionian Sea, South-eastern Mediterranean). By dating the scales and the rhizome using retrospective procedures (lepidochronology), a time series over a period of nine years (19952004) was analysed. Throughout the whole lepidochronological period, the arsenic content in the scales was tenfold higher than that measured in the rhizome with a peak in the lepidochronological year 1996-1997 and a general decrease in the years after. $\mathrm{Pb}$ concentration also showed a tendency to decrease with time, whereas the $\mathrm{Cd}$ and $\mathrm{Cu}$ concentration were increasing. A comparison of the metal level in dead sheaths (scales) and living tissue (leaves) was also performed. The detailed distribution of the trace metals along the leaf axis and in the leaves at different developmental stages (adult, intermediate and juvenile) showed some differences in the metal content. The results also indicate that the arsenic content measured in the leaf blade reflects the high As content measured at the superficial sediments at one of the two sampled sites, demonstrating, for the first time, that $P$. oceanica would be a good indicator for this element.

Keywords: Biomonitoring; Heavy Metals; Ionian Sea; Lepidochronology; Posidonia oceanica

\section{INTRODUCTION}

Detection and monitoring of environmental contamination in the Mediterranean, an almost closed sea, are matters of concern, particularly in heavily urbanized and industrialized areas [1]. The major sources of pollution of surface waters include effluent discharges by industries, urban discharge, atmospheric depositions of pollutants and occasional accidental spills of toxic chemicals. Trace metals are regarded as serious pollutants of the aquatic environment because they are persistent, potentially toxic and naturally bioaccumulated $[2,3]$. There is currently a great interest in the use of living organisms as pollution biomonitors in aquatic ecosystems $[4,5]$. Among these, the seagrasses Zostera marina L. and Posidonia oceanica L. (Delile), key species of the coastal ecosystems, have been used as a metal bioindicator for several decades [6-16]. Arsenic can be taken up, bioaccumulated and biotransformed. Its toxic effects depend on the chemical form of its compounds and there is a growing interest in the quantification and identification of the arsenic in matrices related to human and animal food (e.g. sediments, algae, seagrasses, shellfish). Also it has been observed that $P$. oceanica could "record" past metal contamination [17-23]. Annual heavy metal accumulation can be analyzed by dating fragments of rhizomes and scales (dead sheaths of the leaves) according to plant annual life cycle [17]. Therefore, the time course of such a contamination can be reconstructed over a period ranging between few to many years. Since the early 1950's, the area of Crotone (South-Eastern Mediterranean-Ionian Sea-Calabria, Italy), has become one of the most important petrochemical sites in the South of Italy, with several petrochemical plants and many other industrial installations. About the metal contamination of this zone, there are very few published data [24]; in accordance with Italian law 208 of 30/12/2008, the same industrial area was declared an "area at high risk of environment crisis" and must be subjected to environmental restoration for serious contamination by heavy metals (overall As, $\mathrm{Zn}, \mathrm{Cd}, \mathrm{Cr}$ ). In this context, we performed a lepidochronological analyses by sampling $P$. oceanica from meadows growing in two different sites 
(referred as Disturbed and Control, see section below) in order to dected, for the first time at a local scale, the the level of the trace metals $\mathrm{As}, \mathrm{Cd}, \mathrm{Cu}, \mathrm{Pb}$. The distribution of these metals was also verified with respect to the leaf axis (base vs apical portion) as well as the stage of the leaf development (juvenile vs adult leaf), in order to suggest some differences along a gradient of leaf age. The total arsenic occurrence was furthermore analysed in $P$. oceanica during a relatively long period (nine years) demonstrating the capability of the scales as a preferential organs to biotransfer this toxic contaminant.

\section{MATERIAL AND METHODS}

\subsection{Sampling and Tissues Preparation}

Plants of $P$. oceanica were collected during the summer of 2004 by scuba diving at $10 \pm 1 \mathrm{~m}$ depth from meadows growing in two sites of the East coast of Calabria (Ionian Sea, Italy) (Figure 1). Probably, the two sampling sites were differently impacted: the first meadow was at Località Tonnara $\left(38^{\circ} 54.881^{\prime} \mathrm{N}\right.$ $16^{\circ} 59.845^{\prime} \mathrm{E}$ ), a site very close to the industrial harbour of Crotone, characterized by petrochemical traffic and a metallurgical plant, therefore this site was considered as disturbed (D); the second meadow was located at Capo Bianco $\left(38^{\circ} 55.014^{\prime} \mathrm{N} 17^{\circ} 07.857^{\prime} \mathrm{E}\right)$, away from the bay of Crotone, in the Marine Protected Area (MPA) of Capo Rizzuto (Figure 1); this area is usually considered a pristine region with widespread $P$. oceanica meadows [25] and was considered as a reference site (control: $\mathrm{C}$ ). Plants of $P$. oceanica were collected in each meadow along five different transects that were 50 meters separate; twenty plants were collected in each area with orthotropic rhizomes (vertical growth) at a distance of at least $50-100 \mathrm{~cm}$ apart in order to collect plants belonging to different individuals. The associated superficial sediments were also collected to a depth of about $5 \mathrm{~cm}$.

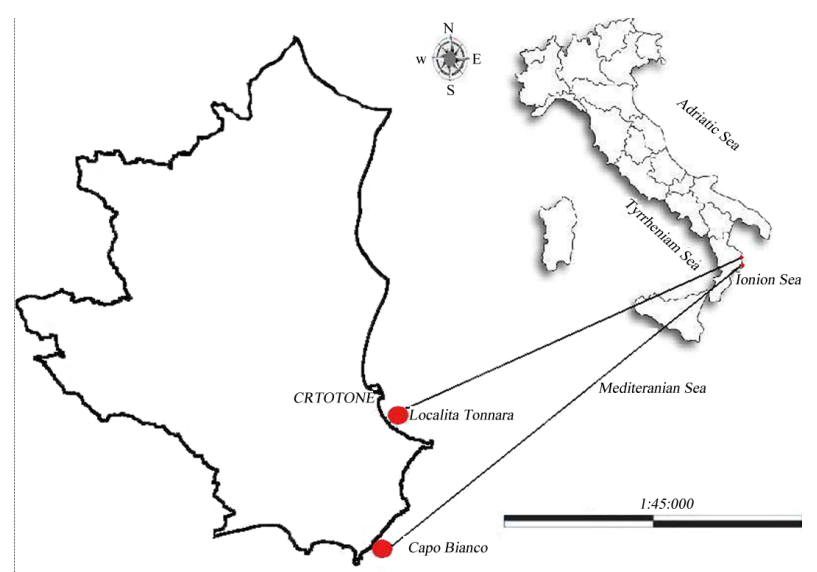

Figure 1. Study area and sampling locations (indicated by circles) along the Ionian coast of Calabria.
The macroscopic epiphytes were then carefully removed by gently scraping and washing and the leaves were separated into adult, intermediate and juvenile leaves according to Giraud (1979) [26]. Each leaf was fractionated in three different portions along the main leaf axis: the tip (last $3 \mathrm{~cm}$ ), the basal portion (the growing one, including part of the blade and the sheath) and the intermediate one. For the lepidochronological analyses, the dead sheaths (scales) and rhizomes were fractioned according to Pergent (1990) [27]. The collected tissues were dried at $105^{\circ} \mathrm{C}$ for $48 \mathrm{~h}$, milled to obtain particles of approximately $100 \mu \mathrm{m}$ in size and then processed for metal analyses. Also the sediment samples, after sieving on $2-\mathrm{mm}$ meshes, were dried at $105^{\circ} \mathrm{C}$ for $48 \mathrm{~h}$.

\subsection{Trace Metal Analyses}

Three subsamples of the ground material $(500 \mathrm{mg} \cdot \mathrm{dw})$ were hot digested in a microwave oven with a mixture of $5 \mathrm{ml}$ of $\mathrm{HNO}_{3} 65 \%$ and $2 \mathrm{ml}$ of $\mathrm{H}_{2} \mathrm{O}_{2} 30 \%$. As, $\mathrm{Cd}, \mathrm{Cu}$ and $\mathrm{Pb}$ concentrations were determined in all samples by an Inductively Coupled Plasma Mass Spectrometer (ICP-MS, Agilent Technologies, 7500 CE Octopole Reaction System). The accuracy of the method was evaluated by its calibration versus an international standard (Stock Standard, Environmental Calibration Standard Agilent; Internal Standard Mix Agilent). A parallel analysis of blanks was also carried out to quantify possible contamination. The obtained data were analysed using the Student's t-test for the paired sample and the results expressed as mean \pm S.E. of three independent replicates for every metal analysed. The trace metals content in different tissue, sites and years were compared by 2-way ANOVA using the software package "R" (The R Foundation for Statistical Computing ISBN 3-90005107-0, version 2.14.1).

\section{RESULTS}

\subsection{Lepidochronological Analyses}

The arsenic content detected in the scales was tenfold higher than in the rhizomes, over all sampled years and in both sites (Figures 2(A) and (B); Tables 1, 2). In particular, the scales sampled at the D site showed a significant higher level of As compared with the $\mathrm{C}$ one in the period $1995-2004$, with a peak of $22.3 \mu \mathrm{g} \cdot \mathrm{g} \cdot \mathrm{dw}^{-1}$ at the D site after which a significantly decreasing trend was detected (Figure 2(A), Table 1). In the same lepidochronological year (1997) a peak of As $\left(2.26 \mu \mathrm{g} \cdot \mathrm{g} \cdot \mathrm{dw}^{-1}\right)$ was also detected in the rhizome, after which a significantly downward trend was observed (Figure 2(B), Table 2). For $\mathrm{Cd}$, comparable levels between scales and rhizomes were measured (Figures 2(C) and (D)) with the highest values $\left(1.89 \mu \mathrm{g} \cdot \mathrm{g} \cdot \mathrm{dw}^{-1}\right)$ in the rhizome in 1995 at the D 

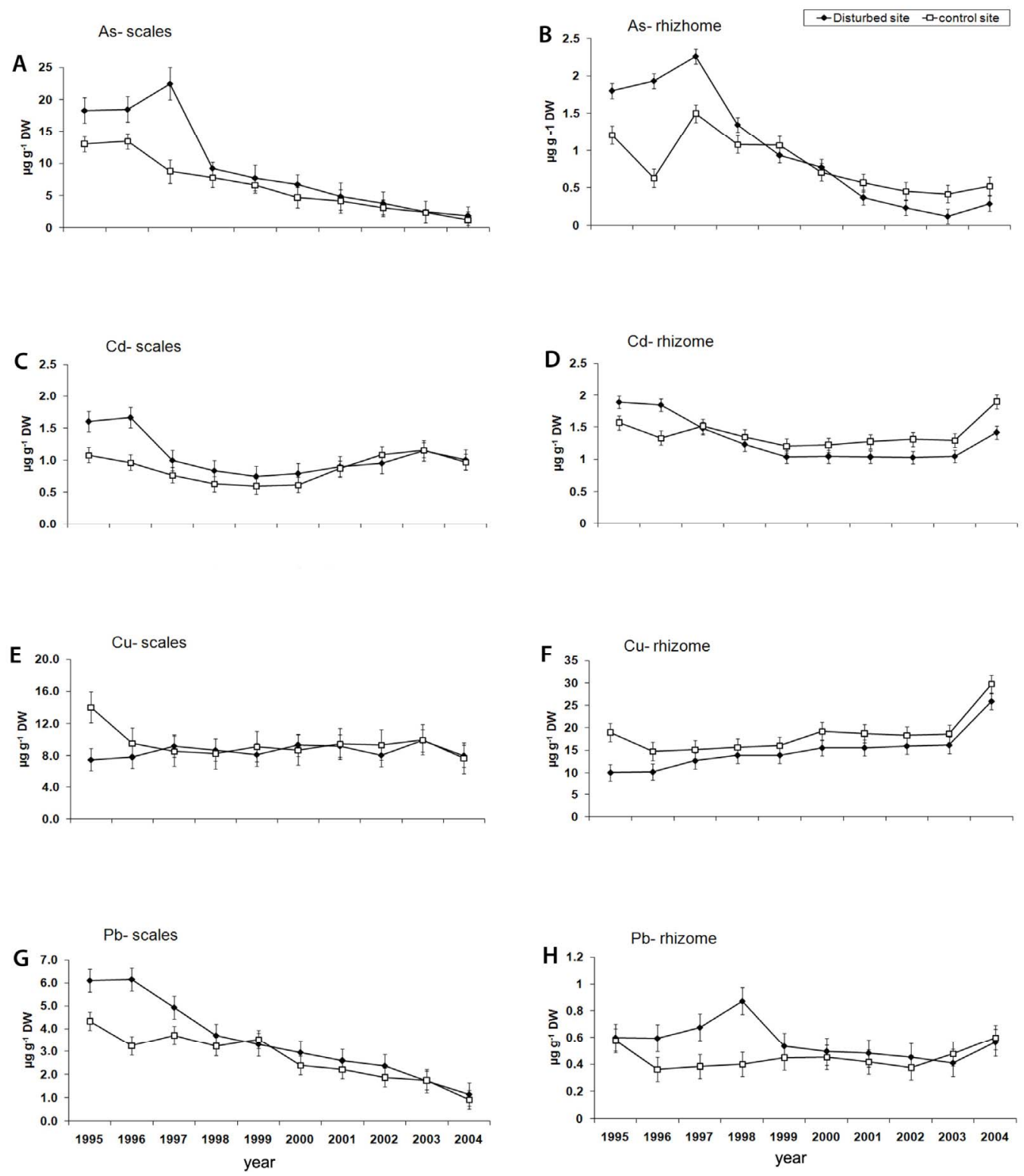

Figure 2. Temporal trend of contamination of heavy metals in $P$. oceanica. Mean $( \pm \mathrm{SE}, \mathrm{n}=5)$ metal concentration $\left(\mu \mathrm{g} \cdot \mathrm{g} \cdot \mathrm{dw}^{-1}\right)$ was measured in scales $(\mathrm{A})(\mathrm{C})(\mathrm{E})(\mathrm{G})$ and rhizomes (B) (D) (F) (H)) sampled at a Disturbed site and a Control site. Scales and rhizomes were dated using the lepidochronological method of Pergent-Martini (1998).

site (Figure 2(D)); both in the scales as in the rhizome a significantly temporal fluctuation was observed (Figures 2(C) and (D); Tables 1 and 2). The content of $\mathrm{Cu}$ in the rhizomes was higher than in the scales with a clear trend to increase during the whole lepidochronological period reaching the maximum values $\left(29.71 \mu \mathrm{g} \cdot \mathrm{g} \cdot \mathrm{dw}^{-1}\right)$ in 2004 in the rhizome of the both sites (Figures 2(E) and (F); Table 2). The concentration of $\mathrm{Pb}$ was significantly higher in the scales than the rhizomes (Figures 2(G) and (H); Tables 1 and 2). The highest $\mathrm{Pb}$ concentration (6.2 $\mu \mathrm{g} \cdot \mathrm{g} \cdot \mathrm{dw}^{-1}$ ) was recorded in the scales in the lepidochronological year 1996 at the D site; after which a constant significantly decline was detected (Figure 2(G); Table 1); otherwise, the $\mathrm{Pb}$ level measured in the rhizomes was approximately constant along the whole lepidochronological period, except a peak in the D site in the year 1998 (Figure 2(H); Table 2).

\subsection{Trace Metals in Different Compartments of $P$. oceanica Plants}

Table 3 shows the distribution of $\mathrm{As}, \mathrm{Cd}, \mathrm{Cu}, \mathrm{Pb}$ in $P$. oceanica specimens and in the upper $5 \mathrm{~cm}$ of sediments sampled at the Disturbed and Control site respectively. The distribution of metals in the plant varied considera- 
Table 1. Mean metal concentration $\left(\mu \mathrm{g} \cdot \mathrm{g} \cdot \mathrm{dw}^{-1}\right) \pm \mathrm{SE}$ and 2-way ANOVA from the scales sampled at the Disturbed and Control site at each time period.

\begin{tabular}{|c|c|c|c|c|c|c|c|c|c|c|c|c|c|c|c|c|}
\hline & \multicolumn{4}{|c|}{ As } & \multicolumn{4}{|c|}{$\mathrm{Cd}$} & \multicolumn{4}{|c|}{$\mathrm{Pb}$} & \multicolumn{4}{|c|}{$\mathrm{Cu}$} \\
\hline & \multicolumn{2}{|c|}{ Disturbed site } & \multicolumn{2}{|c|}{ Control site } & \multicolumn{2}{|c|}{ Disturbed site } & \multicolumn{2}{|c|}{ Control site } & \multicolumn{2}{|c|}{ Disturbed site } & \multicolumn{2}{|c|}{ Control site } & \multicolumn{2}{|c|}{ Disturbed site } & \multicolumn{2}{|c|}{ Control site } \\
\hline 1995 & \multicolumn{2}{|c|}{$18.4 \pm 1.15$} & \multicolumn{2}{|c|}{$13.1 \pm 0.26$} & \multicolumn{2}{|c|}{$1.66 \pm 0.24$} & \multicolumn{2}{|c|}{$1.66 \pm 0.24$} & \multicolumn{2}{|c|}{$1.66 \pm 0.24$} & \multicolumn{2}{|c|}{$1.66 \pm 0.24$} & \multicolumn{2}{|c|}{$1.66 \pm 0.24$} & \multicolumn{2}{|c|}{$1.66 \pm 0.24$} \\
\hline 1996 & \multicolumn{2}{|c|}{$18.5 \pm 0.70$} & \multicolumn{2}{|c|}{$13.6 \pm 0.50$} & \multicolumn{2}{|c|}{$1.66 \pm 0.21$} & \multicolumn{2}{|c|}{$1.66 \pm 0.21$} & \multicolumn{2}{|c|}{$1.66 \pm 0.21$} & \multicolumn{2}{|c|}{$1.66 \pm 0.21$} & \multicolumn{2}{|c|}{$1.66 \pm 0.21$} & \multicolumn{2}{|c|}{$1.66 \pm 0.21$} \\
\hline 1997 & \multicolumn{2}{|c|}{$22.5 \pm 0.89$} & \multicolumn{2}{|c|}{$8.69 \pm 0.70$} & \multicolumn{2}{|c|}{$0.97 \pm 0.08$} & \multicolumn{2}{|c|}{$0.97 \pm 0.08$} & & $7 \pm 0.08$ & 0.97 & $7 \pm 0.08$ & & $7 \pm 0.08$ & 0.97 & $7 \pm 0.08$ \\
\hline 1998 & & $6 \pm 0.34$ & 7.90 & $0 \pm 0.27$ & & $6 \pm 0.11$ & 0.86 & $6 \pm 0.11$ & & $36 \pm 0.11$ & & $6 \pm 0.11$ & & $36 \pm 0.11$ & 0.86 & $6 \pm 0.11$ \\
\hline 1999 & & $5 \pm 0.50$ & 6.79 & $9 \pm 0.38$ & & $4 \pm 0.09$ & 0.74 & $4 \pm 0.09$ & & $4 \pm 0.09$ & 0.74 & $4 \pm 0.09$ & & $74 \pm 0.09$ & 0.74 & $4 \pm 0.09$ \\
\hline 2000 & 6.6 & $7 \pm 0.70$ & 4.77 & $7 \pm 0.25$ & & $0 \pm 0.06$ & 0.80 & $0 \pm 0.06$ & & $30 \pm 0.06$ & 0.80 & $0 \pm 0.06$ & & $30 \pm 0.06$ & 0.80 & $0 \pm 0.06$ \\
\hline 2001 & & $6 \pm 0.85$ & 4.17 & $7 \pm 0.32$ & & $7 \pm 0.05$ & 0.87 & $7 \pm 0.05$ & & $37 \pm 0.05$ & 0.87 & $7 \pm 0.05$ & & $37 \pm 0.05$ & 0.87 & $7 \pm 0.05$ \\
\hline 2002 & & $8 \pm 0.01$ & 3.12 & $2 \pm 0.27$ & & $3 \pm 0.03$ & 1.03 & $3 \pm 0.03$ & & $3 \pm 0.03$ & & $3 \pm 0.03$ & & $3 \pm 0.03$ & 1.03 & $3 \pm 0.03$ \\
\hline 2003 & & $7 \pm 0.46$ & 2.46 & $6 \pm 0.48$ & & $0 \pm 0.12$ & 1.20 & $0 \pm 0.12$ & & $20 \pm 0.12$ & & $0 \pm 0.12$ & & $20 \pm 0.12$ & 1.20 & $0 \pm 0.12$ \\
\hline 2004 & & $3 \pm 0.24$ & 1.31 & $1 \pm 0.23$ & & $6 \pm 0.22$ & 1.06 & $6 \pm 0.22$ & & $6 \pm 0.22$ & 1.06 & $6 \pm 0.22$ & & $6 \pm 0.22$ & 1.06 & $6 \pm 0.22$ \\
\hline Sites & $\begin{array}{l}\text { Ana } \\
\text { Res! }\end{array}$ & $\begin{array}{l}\text { lysis of } \mathrm{Va} \\
\text { oonse: As }\end{array}$ & ariance $\mathrm{T}_{\mathrm{s}}$ & Table & $\begin{array}{l}\text { Ana } \\
\text { Res }\end{array}$ & $\begin{array}{l}\text { lysis of } \mathrm{Va} \\
\text { ponse: } \mathrm{Cd}\end{array}$ & riance $\mathrm{T}$ & Table & $\begin{array}{l}\text { Ana } \\
\text { Res }\end{array}$ & $\begin{array}{l}\text { lysis of } \mathrm{V} \\
\text { ponse: } \mathrm{Pb}\end{array}$ & ariance T & Table & $\begin{array}{l}\text { Anal } \\
\text { Resp }\end{array}$ & $\begin{array}{l}\text { lysis of } \mathrm{Va} \\
\text { ponse: } \mathrm{Cu}\end{array}$ & ariance $\mathrm{Ta}$ & able \\
\hline Years & Df & Sum Sq & Mean Sq & F value & Df & Sum Sq I & Mean Sq & q F value & Df & Sum Sq 1 & Mean Sq & q F value & Df & Sum Sq $I$ & Mean Sq & F value \\
\hline & 1 & 46.03 & 46.029 & $5.197^{*}$ & 1 & $0.157 \quad 0$ & .157 & $6.159^{*}$ & 1 & 3.276 & 3.277 & $7.846^{*}$ & 1 & 4.316 & 4.316 & 1.857 \\
\hline Residuals & 9 & 585.88 & 65.098 & $7.350^{* *}$ & 9 & 1.323 & 148 & $5.767^{* *}$ & 9 & 33.967 & 3.774 & $9.037^{* *}$ & 9 & 13.798 & 1.533 & 0.660 \\
\hline & 9 & 79.72 & 8.857 & & 9 & 0.229 & .026 & & 9 & 3.758 & 0.418 & & 9 & 20.921 & 2.325 & \\
\hline
\end{tabular}

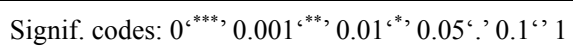

Table 2. Mean metal concentration $\left(\mu \mathrm{g} \cdot \mathrm{g} \cdot \mathrm{dw}^{-1}\right) \pm \mathrm{SE}$ and 2 way ANOVA from the rhizomes sampled at the Disturbed and Control site at each time period.

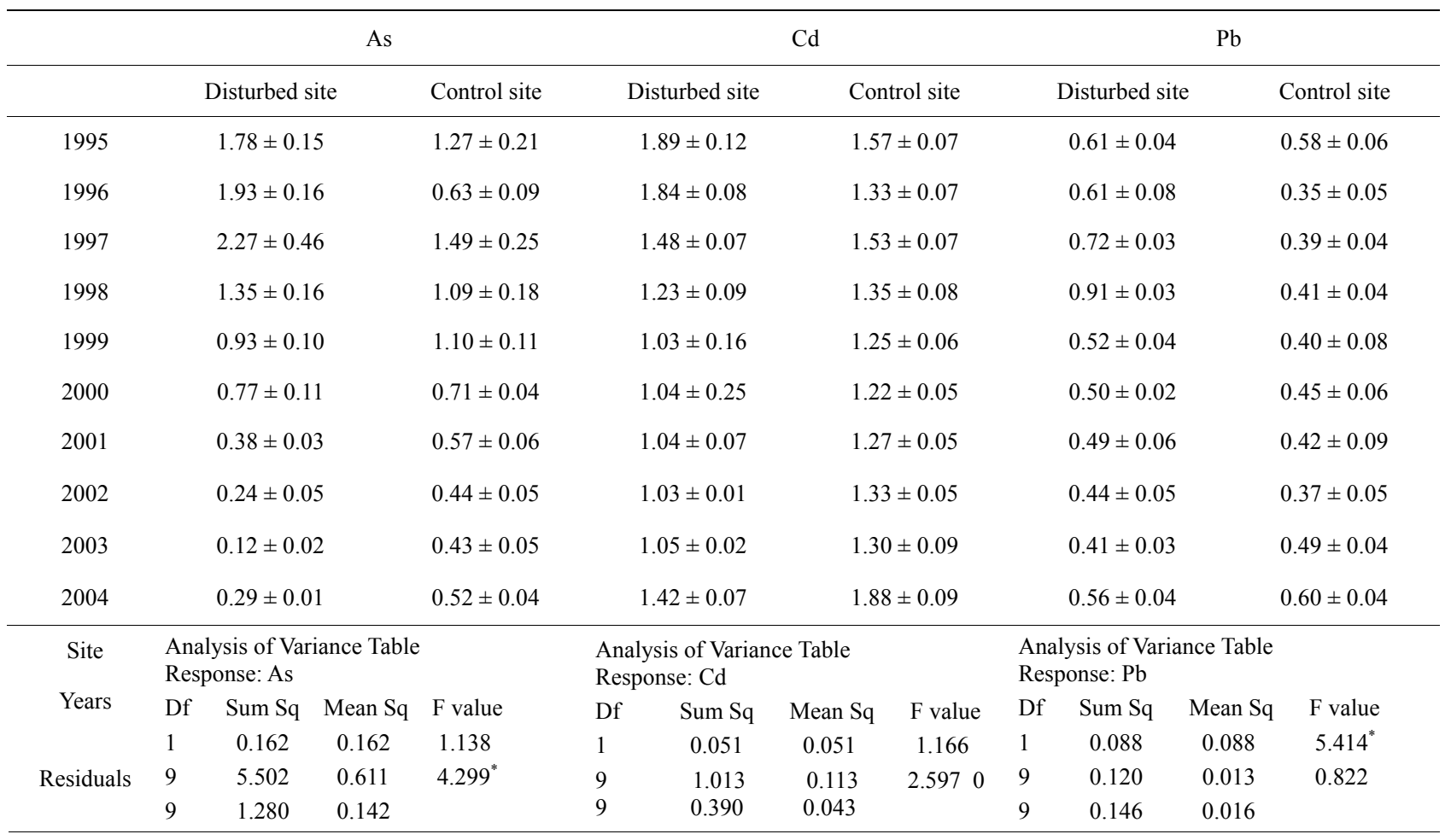

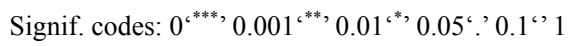


Table 3. Trace metal concentration $\left(\mu \mathrm{g} \cdot \mathrm{g} \cdot \mathrm{dw}{ }^{-1}\right)$ in leaves, scales, rhizomes of Posidonia oceanica collected from meadows at disturbed site control site. Values are means $( \pm \mathrm{SE}, \mathrm{n}=3)$ of samples collected along a transect in five different areas at the same depth. The leaves were considered at different developmental stage (adult, intermediate and juvenile) and fractionated along the leaf axis in a tip, middle and basal portion. For each trace metal, the maximum values measured in the tissues of $P$. oceanica, are in bold.

\begin{tabular}{|c|c|c|c|c|c|c|c|c|}
\hline \multicolumn{9}{|c|}{ Disturbed site Control site } \\
\hline & As & $\mathrm{Cd}$ & $\mathrm{Cu}$ & $\mathrm{Pb}$ & As & $\mathrm{Cd}$ & $\mathrm{Cu}$ & $\mathrm{Pb}$ \\
\hline $\begin{array}{c}\text { Adult } \\
\text { leaves Tip }\end{array}$ & $0.41 \pm 0.04$ & $7.28 \pm 0.03$ & $7.71 \pm 0.03$ & $2.29 \pm 0.02$ & $3.91 \pm 0.02$ & $7.78 \pm 0.05$ & $5.58 \pm 0.02$ & $0.95 \pm 0.01$ \\
\hline Middle & $0.30 \pm 0.03$ & $4.92 \pm 0.04$ & $11.26 \pm 0.05$ & $1.61 \pm 0.01$ & $0.75 \pm 0.10$ & $4.74 \pm 0.03$ & $10.58 \pm 0.03$ & $0.97 \pm 0.01$ \\
\hline Base & $0.15 \pm 0.01$ & $0.71 \pm 0.02$ & $12.40 \pm 0.03$ & $0.79 \pm 0.01$ & $0.20 \pm 0.01$ & $1.32 \pm 0.01$ & $16.68 \pm 0.06$ & $0.42 \pm 0.01$ \\
\hline $\begin{array}{l}\text { Intermediate } \\
\text { leaves Tip }\end{array}$ & $0.36 \pm 0.01$ & $6.28 \pm 0.06$ & $8.33 \pm 0.02$ & $2.52 \pm 0.01$ & $1.90 \pm 0.10$ & $5.35 \pm 0.05$ & $9.25 \pm 0.02$ & $1.19 \pm 0.01$ \\
\hline Middle & $0.26 \pm 0.01$ & $2.46 \pm 0.01$ & $10.86 \pm 0.03$ & $1.01 \pm 0.02$ & $0.71 \pm 0.02$ & $2.75 \pm 0.01$ & $14.03 \pm 0.04$ & $0.76 \pm 0.01$ \\
\hline Base & $0.36 \pm 0.01$ & $1.71 \pm 0.02$ & $34.16 \pm 0.01$ & $2.50 \pm 0.01$ & $0.22 \pm 0.10$ & $5.35 \pm 0.01$ & $34.20 \pm 0.10$ & $0.32 \pm 0.01$ \\
\hline $\begin{array}{c}\text { Juvenile } \\
\text { leaves }\end{array}$ & $0.20 \pm 0.01$ & $1.41 \pm 0.01$ & $22.01 \pm 0.07$ & $0.70 \pm 0.01$ & $0.54 \pm 0.03$ & $2.01 \pm 0.01$ & $26.32 \pm 0.05$ & $0.60 \pm 0.01$ \\
\hline Scales & $1.83 \pm 0.30$ & $1.01 \pm 0.01$ & $7.96 \pm 0.01$ & $1.15 \pm 0.01$ & $1.25 \pm 0.10$ & $0.97 \pm 0.02$ & $7.68 \pm 0.05$ & $0.93 \pm 0.01$ \\
\hline Rhizomes & $0.29 \pm 0.20$ & $0.42 \pm 0.03$ & $25.86 \pm 0.05$ & $0.56 \pm 0.01$ & $0.53 \pm 0.10$ & $1.90 \pm 0.20$ & $29.71 \pm 0.20$ & $0.60 \pm 0.01$ \\
\hline Sediments & $15.5 \pm 0.50$ & $0.12 \pm 0.02$ & $2.17 \pm 0.50$ & $6.63 \pm 0.50$ & $31.75 \pm 0.19$ & $0.06 \pm 0.01$ & $2.03 \pm 0.14$ & $4.57 \pm 0.35$ \\
\hline
\end{tabular}

bly depending on the organ and/or the tissue examined. In the case of As, the concentration measured in leaves as well as scales and rhizomes, differed significantly at the two sampling station with the highest value $(3.91 \pm 0.02$ $\mu \mathrm{g} \cdot \mathrm{g} \cdot \mathrm{dw}^{-1}$ ) in the tip of the adult leaf sampled at the C site; interestingly at the same site the As content in the sediments was higher $\left(31.75 \pm 0.19 \mu \mathrm{g} \cdot \mathrm{g} \cdot \mathrm{dw}^{-1}\right)$ (Table 3) than the contamination limit of $20 \mu \mathrm{g} \cdot \mathrm{g} \cdot \mathrm{dw}^{-1}$, according to Legislative Italian Decree 152/06 of the Environmental Ministry. For the Cd, despite that the sediment of the $\mathrm{D}$ site showed a value of $\mathrm{Cd}$ twice compared to the $\mathrm{C}$ one $\left(1.12 \pm 0.02\right.$ vs $0.06 \pm 0.01 \mu \mathrm{g} \cdot \mathrm{g} \cdot \mathrm{dw}^{-1}$; low contamination limit of $2 \mu \mathrm{g} \cdot \mathrm{g} \cdot \mathrm{dw}^{-1}$ ) its concentration in the plants varied, ranging from $0.42 \pm 0.03 \mu \mathrm{g} \cdot \mathrm{g} \cdot \mathrm{dw}^{-1}$ in the rhizome of the D site, to $7.78 \pm 0.05 \mu \mathrm{g} \cdot \mathrm{g} \cdot \mathrm{dw}^{-1}$ in the tip the adult leaf sampled at the $\mathrm{C}$ one (Table 3). The $\mathrm{Cu}$ level measured in the sediments showed comparable values at the two sampling sites $(2.17 \pm 0.19$ vs $2.03 \pm$ $0.14 \mu \mathrm{g} \cdot \mathrm{g} \cdot \mathrm{dw}^{-1}$ ), values relatively low if compared with the contamination limit of $120 \mu \mathrm{g} \cdot \mathrm{g} \cdot \mathrm{dw}^{-1}$; in the P. oceanica tissues the highest values were detected in the basal portion of intermediate leaves in both the sample sites, with a maximum of $34.2 \pm 0.10$ in the $\mathrm{D}$ site, followed by rhizome and juvenile leaves sampled in the $\mathrm{C}$ site (Table 3). Regarding the $\mathrm{Pb}$, the superficial sediments at the $\mathrm{D}$ site showed an higher level than the $\mathrm{C}$ one $\left(6.63 \pm 0.48 \mu \mathrm{g} \cdot \mathrm{g} \cdot \mathrm{dw}^{-1}\right.$ vs $\left.4.57 \pm 0.35 \mu \mathrm{g} \cdot \mathrm{g} \cdot \mathrm{dw}^{-1}\right)$ but still well below the limit of contamination $\left(100 \mu \mathrm{g} \cdot \mathrm{g} \cdot \mathrm{dw}^{-1}\right)$; notwithstanding in the tissue of $P$. oceanica the highest concentration $\left(2.52 \pm 0.01 \mu \mathrm{g} \cdot \mathrm{g} \cdot \mathrm{dw}^{-1}\right)$ was detected in the intermediate leaves (tip and base) sampled in D site (Table 3).

\section{DISCUSSION}

The lepidochronological data show a relatively high level of As in the scales suggesting that the scales could be an elective compartments to biotransfer this element and also an useful organ for recording the past arsenic contamination. The concentration of As is consistent with the range of $14-21 \mu \mathrm{g} \cdot \mathrm{g} \cdot \mathrm{dw}^{-1}$ reported by Gosselin et al. (2006) [14] in the sheaths of $P$. oceanica but is higher compared to the levels reported for other seagrasses [28-32]. Interestingly, the trend of As is similar both in the scales and in the rhizomes, with the highest values until 1999 followed by a falling trend; this could be related to peak of the industrial activity (overall metallurgical) developed around Crotone city during the decades before 1996-1997; afterwards, some important metallurgical plants were closed. For $\mathrm{Cd}, \mathrm{Cu}$ and $\mathrm{Pb}$, the level reported in $P$. oceanica in this study falls in the lower half of the range reported at the scale of the Mediterranean [15], highlighting a trend that is consistent with the global dynamics of contamination for these elements. Regarding the distribution of these trace metals in the different compartments of the plants; it has been observed differences in the different developmental stage of the leaf and also along the leaf axis, confirming that the metabolic condition and the lifecycle stage of the organ may influence the metal uptake and accumulation. As general role, the data highlighted that the apical tissues of mature leaves showed the highest levels of trace metals except for $\mathrm{Cu}$, confirming its metabolic role during growth and lignifications $[33,34]$. However, the levels of $\mathrm{Cu}$ observed in this study are higher compared to previous studies on P. oceanica [14] suggesting that our sites 
are exposed to theses metal. Regarding the As, our results suggest that total As was mainly concentrated at the tip of mature leaves in the site with high As content in the sediments (Control site). Although the heavy metal contents of submerged macrophytes are often found to be correlated to the levels observed in the sediment, $[35,36]$, the physic-chemical characteristics of sediment may greatly influence this pattern [37,38]. This study, even if at a local scale, confirms that the lepidochronology is a useful tool to provide evidence of past metal contamination in marine environment. Finally, taking into account the level of As measured in the blade and /or in the scales, we suggest that $P$. oceanica would be a suitable biomonitor to assess the present and past As contamination.

\section{ACKNOWLEDGEMENTS}

The authors thank Dr. F. Sprovieri and Mr. F. Cofone (CNR-Institute of Atmospheric Pollution Research-Division of Rende, Cosenza, Italy) for their help in processing samples for heavy metals analysis and Dr. Domenico Iaria for his help in the statistical analysis.

\section{REFERENCES}

[1] Gabrielides, G.P. (1995) Pollution of the Mediterranean Sea. Water Science and Technology, 32, 1-10. doi:10.1016/0273-1223(96)00070-4

[2] Islam, M.D.S. and Tanka, M. (2004) Impacts of pollution on coastal and marine ecosystems including coastal and marine fisheries and approach for management: A review and synthesis. Marine Pollution Bulletin, 48, 624-649. doi:10.1016/j.marpolbul.2003.12.004

[3] Ikem, A. and Egiebor, N.O. (2005) Assessment of trace elements in canned fishes (mackerel, tuna, salmon, sardines and herrings) marketed in Georgia and Alabama (United States of America). Journal of Food Composition and Analyses, 18, 771-787. doi:10.1016/j.jfca.2004.11.002

[4] Zhou, Q., Zhang, J., Fu, J., Shi, J. and Jiang, G. (2008) Biomonitoring: An appealing tool for assessment of metal pollution in the aquatic ecosystem. Analitica Chimica Acta, 606, 135-150. doi:10.1016/j.aca.2007.11.018

[5] Brain, R.A. and Cedergreen N. (2009) Biomarkers in aquatic plants: Selection and utility. Reviews of Environmental Contamination and Toxicology, 198, 49-109. doi:10.1007/978-0-387-09647-6 2

[6] Brix, H. and Lyngby, J.E. (1983) The distribution of some metallic elements in eelgrass (Zostera marina L.) and sediments in the Limfjord, Denmark. Estuarine, Coastal and Shelf Science, 16, 455-467. doi:10.1016/0272-7714(83)90106-3

[7] Brix, H., Lyngby, J.E. and Schierup, H.H. (1983) Elgrass (Zostera marina L.) as indicator organism of trace-metals in the Limfjord, Denmark. Marine Environmental Research, 8, 165-181. doi:10.1016/0141-1136(83)90049-1

[8] Warnau, M., Fowler, S.W. and Teyssié, J.L. (1996) Biokinetics of selected heavy metals and radionuclides in two marine macrophytes: The seagrass Posidonia oceanica and the alga Caulerpa taxifolia. Marine Environmental Research, 41, 343-362. doi:10.1016/S0045-6535(98)00146-5

[9] Schlacher-Hoenlinger, M.A. and Schlacher, T.A. (1998) Differential accumulation patterns of heavy metals among the dominant macrophytes of a Mediterranean seagrass meadow. Chemosphere, 37, 1511-1519. doi:10.1016/S0045-6535(98)00146-5

[10] Pergent-Martini, C. and Pergent, G. (2000) Marine phanerogams as tool in the evaluation of marine trace-metal contamination: An example from the Mediterranean. International Journal of Environmnetal and Pollution, 13, 126-144.

[11] Capiomont, A., Piazzi, L. and Pergent, G. (2000) Seasonal variations of total mercury in foliar tissues of Posidonia oceanica. Journal of the Marine Biological Association, 80, 1119-1123. doi:10.1017/S0025315400003192

[12] Campanella, L., Conti, M.E., Cubadda, F. and Sucapane, C. (2001) Trace metals in seagrass, algae and molluscs from an uncontaminated area in the Mediterranean. Environmental Pollution, 111, 117-126. doi:10.1016/S0269-7491(99)00327-9

[13] Pergent-Martini, C., Leoni, V., Pasqualini, V., Ardizzone, G.D., Balestri, E., Bedini, R., Belluscio, A., Belsher, T., Borg, J., Boudouresque, C.F., Boumaza, S., Bouquegneau, J.M., Buia, M.C., Calvo, S., Cebrian, J., Charbonnel, E., Cinelli, F., Cossu, A., Di Maida, G., Dural, B., Francour, P., Gobert, S., Lepoint, G., Meinesz, A., Molenaar, H., Mansour, H.M., Panayotidis, P., Peirano, A., Pergent, G., Piazzi, L., Pirrotta, M., Renili, G., Romero, J., SanchezLizaso, J.L., Semroud, R., Shembri, P., Shili, A., Tomasello, A. and Velmirov, B. (2005) Descriptors of Posidonia oceanica meadows: Use and application. Ecological Indicators, 5, 213-230.

doi:10.1016/j.ecolind.2005.02.004

[14] Gosselin, M., Bouquegneau, J.M., Lefèbvre, F., Lepoint, G., Pergent, G., Pergent-Martini, C. and Gobert, S. (2006) Trace metal concentrations in Posidonia oceanica of North Corsica (northwestern Mediterranean Sea): Use as biological monitor? BMC Ecology, 11, 6-12.

[15] Lafabrie, C., Pergent-Martini, C., Pergent, G. (2008) Metal contamination of Posidonia oceanica meadows along the Corsican coastline (Mediterranean). Environmental Pollution, 151, 262-268. doi:10.1016/j.envpol.2007.01.047

[16] Lafabrie, C., Pergent, C. and Pergent-Martini, C. (2009) Utilization of the seagrass Posidonia oceanic to evaluate the spatial dispersion of metal contamination. Science of the Total Environment, 407, 2440-2446. doi:10.1016/j.scitotenv.2008.11.001

[17] Calmet, D., Boudouresque, C.F. and Meinesz, A. (1988) Memorization of nuclear atmospheric tests by rhizomes and scales of the Mediterranean seagrass Posidonia oceanica (Linneaus) Delile. Aquatic Botany, 30, 279-294. doi:10.1016/0304-3770(88)90061-7

[18] Pergent-Martini, C. and Pergent, G. (1994) Lepidochronological analysis in the Mediterranean seagrass Posidonia oceanica: State of the art and future developments. Oceanologica Acta, 17, 673-681. 
[19] Roméo, M., Gnassia-Barelli, M., Juhel, T. and Meinesz, A. (1995) Memorization of heavy metals by scales of the seagrass Posidonia oceanica, collected in the NW Mediterranean. Marine Ecology Progress Series, 120, 211-218. doi:10.3354/meps120211

[20] Pergent-Martini, C. (1998) Posidonia oceanica: A biological indicator of past and present mercury contamination in the Mediterranean Sea. Marine Environmental Research, 45, 101-111. doi:10.1016/S0141-1136(97)00023-8

[21] Ancora, S., Bianchi, N., Butini, A., Buia, M.C. and Gambi, M.C. (2004) Posidonia oceanica as a biomonitor of trace elements in the gulf of Naples: Temporal trends by lepidochronology. Environmental Toxicology and Chemestry, 23, 1093-1099. doi:10.1897/02-590

[22] Tranchina, L., Miccichè, S., Bartolotta, A., Braia, M. and Mantegna, R.N. (2005) Posidonia oceanica as historical monitor device of lead concentration in marine environment. Environmental Science and Technology, 39, 30063012. doi:10.1021/es048870u

[23] Lafabrie, C., Pergent, G., Pergent-Martini, C. and Capiomont, A. (2007) Posidonia oceanica: A tracer of past mercury contamination. Environmental Pollution, 148, 688-692. doi:10.1016/j.envpol.2006.11.015

[24] Amodio Cocchieri, R., Arnese, A., Del Prete, U., Giuliano, M. and Roncioni, A. (1993) Heavy metals and polycyclic aromatic hydrocarbons (PAH's) in marine organisms from the Ionian Sea (Italy). Bulletin of Environmental Contamination and Toxicology, 50, 618-625. doi:10.1007/BF00191255

[25] Rende, S.F., Rocca, D., Cappa, P. and Cozza, R. (2006) Monitoring lower limits of Posidonia oceanica meadow in the marine protected area of Capo Rizzuto (KR). Biologia Marina Mediterranea, 13, 206-207.

[26] Giraud, G. (1979) Sur une méthode de mesure et de comptage des structures foliaires de Posidonia oceanica (Linnaeus) Delile. Bulletin de la Musee d'Histoire Naturelle de Paris, 39, 33-39.

[27] Pergent, G. (1990) Lepidochronological analysis of the seagrass Posidonia oceanica (L.) Delile: A standardized approach. Aquatic Botany, 37, 39-54. doi:10.1016/0304-3770(90)90063-Q

[28] Barwick, M. and Maher, W. (2003) Biotransference and biomagnification of selenium, copper, cadmium, zinc, arsenic and lead in a temperate seagrass ecosystem from Lake Macquarie Estuary, NSW, Australia. Marine Environmental Research, 56, 471-502. doi:10.1016/S0141-1136(03)00028-X

[29] Kaldy, J.E. (2006) Carbon, nitrogen, phosphorus and heavy metal budgets: How large is the eelgrass (Zostera marina
L.) sink in a temperate estuary? Marine Pollution Bulletin, 52, 332-356. doi:10.1016/j.marpolbul.2005.11.019

[30] Thomson, D., Maher, W. and Foster, S. (2007) Arsenic and selected elements in marine angiosperm, south-east coast, NSW, Australia. Applied Organometallic Chemestry, 21, 381-385. doi:10.1002/aoc.1229

[31] Llorente-Mirandes, T., Ruiz-Chancho, M.J., Barbero, M., Rubio, R. and Lopez-Sanchez, J.F. (2010) Measurement of arsenic compounds in littoral zone algae from the Western Mediterranean Sea. Occurrence of arsenobetaine. Chemosphere, 81, 867-875. doi:10.1016/j.chemosphere.2010.08.007

[32] Copat, C., Maggiore, R., Arena, G., Lanzafame, S., Fallico, R., Sciacca, S. and Ferrante, M. (2012) Evaluation of a temporal trend heavy metals contamination in Posidonia oceanica (L.) Delile, (1813) along the western coastline of Sicily (Italy). Journal of Environmental Monitoring, 14, 187-192. doi:10.1039/c1em10575b

[33] Lin, C.C., Chen, L.M. and Liu, Z.H. (2005) Rapid effect of copper on lignin biosynthesis in soybean roots. Plant Science, 168, 855-861. doi:10.1016/j.plantsci.2004.10.023

[34] Kim, H.J. and Triplett, B. (2008) Involvement of extracellular $\mathrm{Cu} / \mathrm{Zn}$ superoxide dismutase in cotton fiber primary and secondary cell wall biosynthesis. Plant Signaling and Behavior, 3, 1119-1121. doi: $10.4161 / \mathrm{psb} \cdot 3.12 .7039$

[35] Lyngby, J.E. and Brix, H. (1987) Monitoring of mercury and cadmium in coastal areas using aquatic organisms and sediment. Water Science and Technology, 19, 12391241.

[36] Sánchez-Rodríguez, .I, Huerta-Díaz, M.A., Choumiline, E., Holguín-Quiñones, O. and Zertuche-Gonzále, J.A. (2001) Elemental concentration in different species of seaweeds from Loreto Bay, Baja California Sur, Mexico: Implications for the geochemical control of metals in algal tissue. Environmental Pollution, 114, 145-160. doi:10.1016/S0269-7491(00)00223-2

[37] Sanchiz, C., Garcìa-Carrascosa, A.M. and Pastor, A. (2001) Relationships between sediment physico-chemical characteristics and heavy metal bioaccumulation in Mediter-ranean soft-bottom macrophytes. Aquatic Botany, 69, 63-73. doi:10.1016/S0304-3770(00)00120-0

[38] Nobi, E.P., Dilipan, E., Thangaradjou, T., Sivakumar, K. and Kannan, L. (2010) Geochemical and geo-statistical assessment of heavy metal concentration in the sediments of different coastal ecosystems of Andaman Islands, India. Estuarine, Coastal and Shelf Science, 87, 253-264. doi:10.1016/j.ecss.2009.12.019 